\title{
Hubungan antara citra tubuh dan konformitas terhadap perilaku konsumtif pada remaja putri di Universitas Udayana
}

\author{
Ni Luh Ayu Putri Windayanti dan Supriyadi \\ Program Studi Sarjana Psikologi, Fakultas Kedokteran, Universitas Udayana \\ paupasli@yahoo.com
}

\begin{abstract}
Abstrak
Perilaku konsumtif adalah tindakan yang dilakukan individu untuk membeli barang atau jasa yang berlebihan dan tanpa pertimbangan yang rasional, demi kepuasan fisik dan dorongan untuk memuaskan keinginan. Munculnya perilaku konsumtif tidak terlepas dari adanya faktor-faktor yang mempengaruhi seperti konformitas dan citra tubuh. Penelitian ini bertujuan untuk mengetahui peran citra tubuh dan konformitas pada remaja putri di Universitas Udayana. Pengambilan sampel dilakukan dengan teknik one stage cluster random sampling. Responden dalam penelitian ini adalah mahasiswi di Universitas Udayana yang berjumlah 227 orang. Alat ukur yang digunakan dalam penelitian ini adalah Skala Perilaku Konsumtif, Skala Konformitas, dan Skala Citra tubuh yang sudah diuji reliabilitas dan validitasnya. Hasil uji regresi menunjukkan koefisien regresi sebesar 0,335 dan koefisien determinasi sebesar 0,113, dengan signifikasi sebesar $0,000(\mathrm{p}<0,05)$ yang berarti citra tubuh dan konformitas secara bersama-sama berperan sebesar $11,3 \%$ dalam menjelaskan varian perilaku konsumtif. Konformitas secara mandiri diyakini dapat beperan dalam mempengaruhi perilaku konsumtif dan citra tubuh secara mandiri tidak berperan secara signifikan terhadap perilaku konsumtif. Citra tubuh hanya dapat berperan ketika bersama-sama dengan variabel konformitas.
\end{abstract}

Kata kunci: Perilaku konsumtif, konformitas, citra tubuh.

\begin{abstract}
Consumptive behavior is the act of the individual to buy goods or services in excessive amount and without rational considerations, for the sake of physical satisfaction and encouragement to satisfy the desire. The emergence of consumptive behavior is inseparable from the existence of influencing factors such as conformity and body image. This study aims to determine the role of body image and conformity on female adolescence in Udayana University. Sampling was done by one stage cluster random sampling technique. Respondents in this study were female students at Udayana University, amounting to 227 people. Measuring tool that used in this research is Consumptive Behavior Scale, Conformity Scale, and Body Image Scale and have been tested its reliability and validity. The regression test results showed regression coefficient of 0.335 and the coefficient of determination of 0.113 , with significance of 0.000 $(\mathrm{p}<0.05)$ which means body image and conformity together account for $11.3 \%$ in explaining variant consumptive behavior. The conformity independently believed to be able to influence consumptive behavior and the body image does not play a significant role in consumptive behavior. Body image can only play a role when together with the conformity variable.
\end{abstract}

Keywords: Consumptive behavior, conformity, body image. 


\section{LATAR BELAKANG}

Manusia pada dasarnya selalu berupaya untuk memenuhi kebutuhan primer, sekunder maupun tersier. Pada zaman dahulu, konsumsi masyarakat hanya terbatas pada pemenuhan kebutuhan saja dan menahan keinginan untuk mengikuti trend yang ada karena jumlah produksi barang yang masih sedikit. Masalah ini cukup terbantu karena teknologi baru, yaitu munculnya mesin-mesin produksi yang canggih dan penggunaan komputer untuk mendesain produk dengan memanfaatkan segala sumber daya yang ada.

Berkat perkembangan teknologi yang sudah maju, produsen dapat memproduksi barang dengan waktu cepat dan dalam jumlah yang besar sehingga menghasilkan jumlah produksi barang yang lebih banyak. Adanya kemajuan dalam peningkatan produksi secara nyata menyebabkan hasrat komsumtif dan daya beli yang bertambah (Santoso, 2006). Masyarakat lebih mudah mencari apa yang mereka inginkan dan tergoda oleh rayuan-rayuan produsen yang menawarkan barang ataupun jasa. Para produsen akan mengemas produk sedemikian rupa, serta memanimpulasi cara pandang seseorang, sehingga dapat mempengaruhi emosi dan sikap konsumen dalam pengambilan keputusan untuk membeli suatu barang yang menjauhkan aspek rasional dan fungsional dari pembelian barang tersebut.

Kondisi tersebut membawa kebiasaan dan berubahnya gaya hidup dalam waktu yang relatif singkat menuju ke arah yang semakin mewah serta berlebihan sehingga nantinya akan memicu perilaku konsumtif pada masyarakat. Terlihat dari perkembangan di masyarakat, perilaku konsumtif masyarakat sekarang ini tidak hanya pada konsumsi primer dan sekunder saja, tetapi konsumsi akan kebutuhan tersier hampir menggeser konsumsi primer dan sekunder.

Perilaku konsumtif sendiri adalah perilaku konsumsi berlebihan dimana individu mendahulukan keinginan daripada kebutuhan. Kebutuhan dan keinginan seseorang yang ingin selalu dipenuhi, membuat individu melakukan suatu upaya untuk memenuhi kebutuhan dan keinginan tersebut (Tambuan, 2001). Aktivitas yang biasa dilakukan untuk memenuhi keinginan salah satunya adalah dengan berbelanja. Solomon (2007) mengatakan bahwa pola perilaku berbelanja kebanyakan muncul karena individu tidak mampu mengendalikan dorongan untuk membeli.

Bagi produsen, sasaran yang paling potensial adalah remaja. Perilaku konsumtif terbentuk pada saat remaja, dan akan berkembang hingga dewasa sebagai orang-orang dengan gaya hidup konsumtif (Tambuan, 2001). Masa remaja merupakan transisi pekembangan antara masa kanak-kanak dan masa dewasa yang dimana individu akan mengalami perubahan besar pada fisik, kognitif dan psikososial (Papalia, Old, \& Fieldman, 2013). Mahasiswi di Perguruan Tinggi adalah individu yang umumnya telah memasuki masa remaja akhir yaitu dalam rentang usia 18 hingga 21 tahun (Monks, Knoers, \& Hadinoto, 2014). Pada fase remaja ini, keinginan untuk membeli yang cukup tinggi akan muncul.
Menurut Zebua dan Nurdjayati (2001), remaja khusunya remaja putri merupakan kelompok konsumen yang memiliki karakteristik seperti mudah tertarik dengan mode, mudah terbujuk dengan iklan dan rayuan penjual, tidak hemat, kurang realistis, romantis dan impulsive (Tambuan, 2001). Karakteristik ini memudahkan remaja putri dalam perilaku pembelian yang kurang efisien. Remaja memiliki kecenderungan untuk tetap tampil menarik sehingga perilaku berbelanja akan dilakukan dengan anggapan bahwa pakaian serta aksesoris seperti tas, sepatu dan kosmetik dapat menunjang penampilan.

Remaja tidak segan untuk membeli barang-barang yang mereka anggap menarik dan mengikuti gaya mode yang sedang populer, karena tidak ingin dianggap kuno atau kurang gaul. Padahal gaya mode sendiri akan selalu berubah, sehingga para remaja tidak akan pernah puas dengan produkproduk yang sudah dimiliki saat ini (Djudiyah dan Hadipranata, 2002). Hal ini mengakibatkan remaja menjadi cenderung membeli barang yang mereka inginkan secara berlebihan dan bukan berdasarkan apa yang dibutuhkan. Berdasarkan hasil wawancara pada salah satu mahasiswi Universitas Udayana pada bulan November 2017, berkembangnya perbelanjaan daring melalui internet membuat individu lebih mudah untuk mencari dan membeli barang yang diinginkan.

Adanya keinginan untuk tampil menarik, salah satunya disebabkan oleh adanya perasaan tidak puas serta cara pandang seseorang terhadap diri sendiri yang berhubungan dengan citra tubuh. Citra tubuh didefisinisikan sebagai persepsi seseorang yang menyeluruh mengenai tubuh, termasuk pemikiran, perasaan dan reaksi seseorang mengenainya (Adi, 2008). Grogan (2008) menyebutkan bahwa citra tubuh merupakan persepsi, pemikiran dan perasaan seseorang terhadap badannya, termasuk didalamnya konsep psikologis, seperti persepsi dan sikap terhadap badan.

Menurut Smolak (dalam Cash \& Pruzinksy, 2002) citra tubuh memiliki dua konsep yaitu citra tubuh negatif dan citra tubuh yang positif. Citra tubuh negatif dimiliki oleh individu yang menganggap bahwa tubuh mereka tidak menarik dibandingkan orang lain, sedangkan citra tubuh positif dimiliki oleh individu yang melihat bahwa tubuhnya menarik dibandingkan orang lain dan mereka merasa puas dengan keadaan fisiknya. Persepsi tentang citra tubuh di kalangan masyarakat luas berkisar dari penilaian yang sangat negatif hingga sangat positif. Persepsi akan citra tubuh tergantung dari faktor lain seperti usia, keluarga maupun teman sebaya, sehingga tingkat kecemasan akan citra tubuh juga akan bervariasi pada setiap individu.

Citra tubuh yang muncul pada masing-masing individu dapat mempengaruhi diri, terutama perempuan dalam memilih penampilannya. Penampilan serta kecantikan merupakan modal utama bagi mereka, terutama saat berkembangnya pemikiran di masyarakat bahwa seorang perempuan harus tampil cantik dan menarik, maka para perempuan berupaya untuk mewujudkan hal tersebut. Sebagian besar remaja putri lebih sering merasa tidak puas dengan berat badan serta bentuk tubuh yang dimiliki dan selalu membandingkan 
tampilan diri dengan model yang ditayangkan oleh media massa yang menekankan pada tubuh yang ramping (Anin, Rasminin \& Nuryati, 2007). Terlebih lagi akibat dari pengaruh hormonal dan perkembangan biologis yang pesat pada fase remaja, banyak remaja putri yang mengalami pertumbuhan jerawat serta ukuran tubuh yang makin membesar. Remaja akan disibukkan dengan penampilan serta mengembangkan citra individual mengenai gambaran tubuh diri sendiri. Remaja akan melihat cermin setiap hari, bahkan berjam-jam untuk melihat apakah dapat ditemukan perubahan atau sesuatu yang berbeda pada tubuh mereka (Santrock, 2003). Perubahan ini menyebabkan remaja putri seringkali tidak suka dengan keadaan tubuh diri sendiri yang mengakibatkan munculnya rasa tidak percaya diri.

Remaja menjadi lebih sensitif terhadap citra tubuh dan akan terdorong untuk melakukan berbagi upaya agar penampilan fisik sesuai dengan keingan dan tuntutan sosial di masyarakat. Banyak remaja yang berusaha menggapainya dengan bantuan kosmetik, mengikuti mode terbaru, menata rambut hingga melakukan koreksi di berbagai bagian wajah dan tubuh. Keinginan untuk pemenuhan kebutuhan agar tampil menarik dapat menyebabkan munculnya perilaku konsumtif pada remaja. Dari hasil wawancara yang dilakukan kepada salah satu mahasiswi di Universitas Udayana pada bulan November 2017, subjek mengatakan bahwa akibat bekas jerawat yang muncul selama masa pubertas, sekarang ini subjek harus selalu menggunakan riasan wajah karena merasa tidak percaya diri apabila harus tampil dengan wajah tanpa riasan. Akibat penggunaan riasan setiap hari, subjek menjadi senang mencoba berbagai alat-alat kecantikan seperti mengkoleksi berbagai warna perona mata dan juga bibir. Subjek mengaku bahwa tidak sedikit biaya yang harus dikeluarkan, namun keinginan untuk membeli produk yang menarik perhatian tidak dapat ditahan.

Perilaku konsumtif juga dapat dipengaruhi oleh faktor sosial yang terdiri dari beberapa faktor, salah satunya adalah kelompok acuan. Pengaruh kelompok acuan terhadap perilaku konsumtif antara lain menentukan produk dan mereka yang digunakan sesuai dengan aspirasi kelompok. Penyesuaian dengan kelompok menyebabkan perubahan keyakinan yang merupakan reaksi terhadap tekanan kelompok. Seseorang bisa masuk suatu kelompok apabila memiliki kecocokan antara tujuan dan norma yang berlaku dalam kelompok tersebut (Prasetijo dan Ihalauw, 2005). Hal ini dikuatkan dengan fakta bahwa remaja banyak dipengaruhi oleh teman kelompoknya. Remaja akan menghabiskan waktu dalam kelompok dua kali lebih banyak daripada dengan orangtua mereka (Santrock, 2003). Kelompok acuan merupakan tempat bagi remaja untuk mendapatkan dukungan, penjelasan serta opini tentang bagaimana mereka di mata orang lain.

Dalam kelompok acuan akan terjadi konformitas. Menurut Baron dan Bryne (2003), konformitas adalah penyesuian perilaku remaja untuk menganut pada norma kelompok, menerima ide dan peraturan-peraturan yang menunjukkan bagaimana seharusnya individu berperilaku. Konformitas terjadi apabila individu mengadopsi sikap atau perilaku orang lain karena merasa didesak oleh orang lain, baik secara nyata ataupun hanya bayangan saja (Santrock, 2003). Desakan untuk konform pada kelompok acuan sangat kuat selama masa remaja.

Konformitas dengan kelompok merupakan suatu hal umum yang sering terjadi di masyarakat. Hal tersebut dapat dilihat dari refrensi remaja dalam memilih pakaian, aliran musik, bahasa, dan nilai-nilai yang ada. Remaja juga akan cenderung berpenampilan seperti yang di kehendaki kelompoknya (Hurlock, 2006). Kebutuhan untuk diterima dan menjadi sama dengan orang lain dan keinginan untuk diterima menjadi suatu bagian dari suatu kelompok menyebabkan remaja berusaha mengikuti apa yang sedang menjadi mode dan akan terjerat dalam perilaku konsumtif (Tambuan, 2001). Adanya keinginan untuk konformitas terhadap teman kelompok ditemukan pada mahasiswi Universitas Udayana yang telah diwawancarai pada bulan November 2017. Subjek mengatakan bahwa saat berkumpul ada keinginan untuk dapat mengikuti pembicaraan teman-teman kelompoknya tentang kosmetik, sehingga subjek berpikiran untuk mencoba memakai kosmetik dan meminta rekomendasi dari temanteman kelompoknya.

Berdasarkan pemaparan diatas, ditemukan bahwa pengaruh citra tubuh dan konformitas terhadap munculnya perilaku konsumtif pada remaja putri yaitu mahasiswi Universitas Udayana merupakan suatu permasalahan yang perlu dikaji lebih lanjut karena kedepannya apabila perilaku konsumtif terus berlanjut maka akan menyebabkan kerugian pada remaja secara ekonomis yaitu inefisensi pada biaya hidup. Maka dari itu penelitian ini diadakan, dengan tujuan untuk melihat apakah terdapat hubungan antara citra tubuh dan konformitas dengan perilaku konsumtif pada mahasiswi di Universitas Udayana.

Melalui penelitian ini diharapkan secara teoritis dapat menambahkan ilmu pengetahuan terutama dalam bidang Psikologi Industri dan Organisasi, Psikologi Perkembangan dan juga Psikologi Sosial. Bagi remaja diharapkan dapat memberikan informasi akan pertumbuhan serta perkembangan, terutama dalam penampilan fisik serta penyesuaian dalam tingkat konformitas selama remaja, agar nantinya tidak terjerumus dalam perilaku konsumtif. Bagi orangtua, penelitian ini diharapkan dapat menjadi masukan dalam membentuk pola pikiran anak untuk membeli barang sesuai dengan kebutuhan dan mencegah perilaku konsumtif pada anak. Selain itu, bagi peneliti selanjutnya diharapkan penelitian ini dapat dijadikan sebagai refrensi untuk penelitian lain yang relevan.

\section{METODE PENELITIAN}

\section{Variabel dan Definisi Operasional}

Variabel tergantung dalam penelitian ini adalah perilaku konsumtif dan variabel bebas dalam penelitian ini adalah konformitas serta citra tubuh. Adapun definisi operasional masing-masing variabel dalam penelitian adalah sebagai berikut: 
Perilaku Konsumtif

Perilaku konsumtif adalah tindakan individu untuk membeli atau mengkonsumsi barang dan jasa secara berlebihan yang bukan merupakan prioritas kebutuhannya. Perilaku konsumtif akan diukur menggunakan kuesioner yang dibuat peneliti menggunakan skala Likert berdasarkan aspek-aspek perilaku konsumtif yang dikemukakan oleh Engel, Blackwell, dan Miniard (2008), yaitu: impulsif, tidak rasional dan boros.

Citra Tubuh:

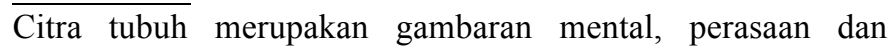
persepsi individu yang berkaitan dengan bentuk tubuh, berat badan serta ukuran tubuh yang mengarah terhadap kepuasan penampilan fisiknya. Citra tubuh dalam penelitian ini akan diukur menggunakan kuesioner yang dibuat peneliti menggunakan skala Likert berdasarkan aspek-aspek yang disampaikan oleh Cash dan Pruzinsky (2002), yaitu: evaluasi penampilan, orientasi penampilan, kepuasan area tubuh, kecemasan akan kegemukan, dan pengkategorian ukuran tubuh.

\section{Konformitas}

Konformitas merupakan perubahan sikap dan perilaku individu sebagai usaha menyesuaikan diri dengan norma dan harapan yang dibentuk kelompok baik nyata atau hanya dibayangkan oleh individu sendiri, agar dapat diterima dalam kelompok dan sebagai bentuk interaksi dalam kelompok. Konformitas dalam penelitian ini akan diukur menggunakan kuesioner yang dibuat peneliti menggunakan skala Likert berdasarkan aspek-aspek konformitas menurut Martin dan Hawstone (2003), yaitu pengaruh normatif dan pengaruh informasional.

\section{Subjek Penelitian}

Populasi dalam penelitian ini adalah Mahasiswi Universitas Udayana. Untuk mengambil sample agar dapat mewakili populasi, maka dalam pemilihan sampel ditentukan dua kriteria yaitu subjek adalah perempuan berusia 18 hingga 21 tahun dan berstatus sebagai mahasiswi aktif di Universitas Udayana.

Teknik pengambilan sampel menggunakan teknik cluster random sampling. Cluster random sampling adalah teknik pengambilan anggota sampel yang dilakukan secara acak berdasarkan kelompoknya atau teknik pengambilan sampel yang dilakukan apabila obyek yang akan diteliti atau sumber data sangat luas. Terdapat dua tahap dalam teknik cluster sampling ini yaitu one stage sampling dan two stage sampling. Pada penelitian ini digunakan one stage sampling yang artinya pengambilan anggota sampling dari area yang terpilih dilakukan secara acak tanpa memperhatikan strata yang ada dalam populasi tersebut sehingga data dari semua anggota sampel yang terpilih akan dikumpulkan tanpa terkecuali (Sugiyono, 2012).

Setelah menentukan daerah populasi yaitu remaja putri di Universitas Udayana, kemudian dilakukan pengundian secara acak fakultas yang akan terpilih sebagai sampel penelitian. Melalui pengundian terpilih Fakultas Kedokteran, Fakultas Matematika dan Ilmu Pengetahuan, Fakultas Ekonomi dan Bisnis, Fakultas Hukum, Fakultas Teknik, Fakultas Ilmu
Politik dan Sosial serta Fakultas Ilmu Budaya sebagai sampel penelitian.

Dalam pengambilan sampel, diperlukan pertimbangkan untuk ukuran sampel atau jumlah anggota sampel yang akan digunakan. Pada data populasi mahasiswa Universitas Udayana dari Biro Administrasi Akademik Universitas Udayana, didapatkan populasi mahasiswi di Universitas Udayana sebanyak 8.626 orang (tingkat kesalahan atau signifikansi $10 \%$ ). Penentuan jumlah sampel dalam penelitian ini menggunakan rumus Slovin, yang merupakan sebuah rumus atau formula untuk menghitung jumlah sampel minimal. Adapun perhitungan jumlah sampel dilakukan dengan cara berikut:

$\mathrm{n}=\mathrm{N} / \mathrm{N} .\left(\mathrm{d}^{2}\right)+1$

$\mathrm{n}=8626 / 8626 .\left(0,1^{2}\right)+1=98,853$

Keterangan:

$\mathrm{n}=$ Jumlah Sampel

$\mathrm{N}=$ Jumlah Populasi

$\mathrm{d}=$ Tingkat Kesalahan atau signifikansi

Dari hasil perhitungan diatas sebesar 98,853 dengan tingkat kesalahan $10 \%$ yang dibulatkan keatas menjadi 99 , sehinga pengambilan sampel pada penelitian ini minimal berjumlah 99 subjek. Berdasarkan sampel minimal yaitu 99 subjek, peneliti menetapkan untuk menyebar 240 kuesioner yang dimana lebih banyak dari minimal pengambilan untuk mengatasi kesalahan sampel.

\section{Tempat Penelitian}

Pelaksanaan penelitian ini dilakukan pada bulan Februari, yaitu pada tanggal 8 Februari 2018 di Fakultas Kedokteran dan Fakultas Ekonomi dan Bisnis, 9 Februari 2018 di Fakultas Ilmu Politik dan Sosial serta Fakultas Teknik, 10 Februari 2018 di Fakultas Ilmu Budaya dan Fakultas Hukum, serta tanggal 11 Februari 2018 di Fakultas Matematika dan Ilmu Pengetahuan Alam. Pada penelitian ini jumlah keseluruhan kuesioner yang disebar adalah sebanyak 240 kuesioner, namun jumlah yang kembali dan memenuhi syarat untuk dapat dianalisis adalah sebanyak 227 kuesioner. Berdasarkan hal tersebut jumlah responden dalam penelitian ini sudah memenuhi kriteria sampel minimum yang sudah ditetapkan sebelumnya.

\section{Alat Ukur}

Alat ukur yang digunakan dalam pengumpulan data untuk penelitian ini terdiri atas tiga skala yaitu skala perilaku konsumtif, skala citra tubuh, dan skala konformitas. Semua skala yang digunakan menggunakan model skala Likert. Skala Likert yang digunakan telah dimodifikasi, yaitu menghilangkan pilihan ragu-ragu atau netral, sehingga subjek akan memilih jawaban yang pasti ke arah yang sesuai atau tidak sesuai dengan dirinya.

Skala dibuat dengan pernyataan favorable dan unfavorable dengan empat alternatif jawaban yang disediakan, yaitu sangat sesuai (SS), sesuai (S), tidak sesuai (TS), sangat tidak sesuai (STS). Penilaian aitem favorable mulai dari skor 4 (sangat sesuai), skor 3 (sesuai), skor 2 (tidak sesuai), dan skor 1 (sangat tidak sesuai). Sedangkan penilaian aitem unfavorable 
dimulai dari skor 1 (sangat sesuai), skor 2 (sesuai), skor 3 (tidak sesuai), dan skor 4 (sangat tidak sesuai).

Skala Perilaku Konsumtif disusun berdasarkan aspek-aspek perilaku konsumtif menurut Engel, Blackwell dan Miniard (2008) yang terdiri dari 34 aitem, Skala Citra Tubuh disusun berdasarkan aspek-aspek yang dikemukakan oleh Cash dan Pruzinsky (2002) yang terdiri dari 22 aitem dan Skala Konformitas dalam penelitian ini disusun dengan menggunakan aspek-aspek konformitas menurut Martin dan Hewstone (2003) yang terdiri dari 25 aitem. Skala bersifat unidimensional yang artinya skala hanya untuk mengukur satu dimensi yaitu perilaku konsumtif secara keseluruhan dari variabel yang multidimensi.

Sebelum melakukan analisis data, terlebih dahulu dilakukan uji validitas dan reliabilitas. Pengujian validitas isi dalam penelitian ini dilakukan dengan menggunakan professional judgement bersama dosen pembimbing dan dosen psikologi. Pengujian validitas konstrak dilakukan dengan melihat $r$ hitung harus lebih besar dari $r$ standar atau memiliki nilai corrected total item correlation lebih besar sama dengan 0,30 $(\geq 0,30)$. Namun apabila dalam pengujian validitas jumlah aitem yang memadai tidak mencukup jumlah yang diinginkan, maka peneliti dapat mempertimbangkan untuk menurunkan batas kriteria menjadi 0,25 sehingga jumlah aitem yang diinginkan dapat terpenuhi (Azwar, 2010b). Pengujian reliabilitas dalam penelitian ini menggunakan teknik analisa Cronbach Alpha. Suatu aitem yang memiliki nilai Cronbach Alpha di atas 0,60 telah dikatakan baik dan reliabel (Sugiyono, 2012).

Hasil uji validitas Skala Perilaku Konsumtif memiliki nilai korelasi aitem total yang berkisar pada rentang 0,262 sampai 0,615. Hasil uji reliabilitas Skala Perilaku Konsumtif dengan menggunakan teknik Alpha Cronbach menunjukkan nilai koefisien Alpha $(\alpha)$ sebesar 0,890 yang memiliki arti bahwa Skala Perilaku Konsumtif mampu mencerminkan 89\% dari variasi skor murni responden. Hasil uji validitas Skala Konformitas memiliki nilai korelasi aitem total yang berkisar pada rentang 0,264 sampai 0,607. Hasil uji reliabilitas Skala Konformitas menunjukkan nilai koefisien Alpha ( $\alpha)$ sebesar 0,863 yang memiliki arti bahwa Skala Konformitas mampu mencerminkan $86,3 \%$ dari variasi skor murni responden. Hasil uji validiatas Skala Citra Tubuh memiliki nlai korelasi aitem total yang berkisar pada rentang 0,284 sampai 0,744. Hasil uji reliabilitas Skala Citra Tubuh menunjukkan nilai koefiesien Alpha $(\alpha)$ sebesar 0,914 memiliki arti bahwa Skala Citra tubuh mampu mencerminkan $91,4 \%$ dari variasi skor murni responden. Dari analisis validitas dan reliabilitas tersebut dapat disimpulkan bahwa ketiga skala tersebut diatas layak untuk dijadikan alat ukur pada penelitian ini.

\section{Teknik Analisis Data}

Uji asumsi dalam penelitian ini menggunakan uji normalitas dengan teknik analisa Kolmogorov-Smirnov (K-S), uji linieritas dengan teknik Ramsey Test, uji multikolinieritas melihat nilai Tolerance dan Variance Inflation Factor (VIF), dan uji heteroskedastisitas dengan uji Glejser. Uji hipotesis dilakukan dengan menggunakan uji Regresi Ganda. Analisis regresi digunakan untuk mengetahui besarnya nilai variabel bebas dalam menjelaskan variabel tergantung pada penelitian serta untuk memprediksi perubahan nilai variabel tergantung jika nilai variabel bebas diubah (Sugiyono, 2012).

\section{HASIL PENELITIAN}

\section{Karakteristik Subjek}

Responden pada penelitian ini adalah mahasiswi di Universitas Udayana dari beberapa fakultas diantaranya: Fakultas Kedokteran, Fakultas Ilmu Budaya, Fakultas Teknik, Fakultas Matematika dan Ilmu Pengetahuan Alam, Fakultas Fakultas Ekonomi dan Fakultas Ilmu Politik dan Sosial yang berjumlah 227 orang. Mayoritas responden yang mengikuti penelitian ini adalah berada pada semester empat sebanyak 81 orang dengan persentase sebesar 35,7\%. Apabila dilihat dari usia, mayoritas responden berada pada usia 20 tahun sebanyak 68 orang dengan persentase sebesar 29,9\%. Mayoritas responden yang mengikuti penelitian ini memiliki berat badan dalam rentang 49-61 kg sebanyak 126 orang dengan persentase sebesar 55,5\%. Apabila dilihat dari tinggi badan, responden yang mengikuti penelitian ini adalah memiliki tinggi badan dalam rentang 154-163 cm sebanyak 127 orang dengan persentase sebesar 55,6\%. Mayoritas responden yang mengikuti penelitian ini adalah memiliki body mass index berada dalam kategori normal sebanyak 176 orang dengan persentase sebesar 77,5\%. Apabila dilihat dari barang yang paling sering dibeli, mayoritas responden lebih sering membeli pakaian yaitu sebanyak 147 orang dengan persentase sebesar 64,8\%. Apabila dilihat dari frekuensi berbelanja setiap bulan, mayoritas responden berbelanja sebanyak tiga kali dalam sebulan sebanyak 97 orang dengan persentase sebesar 42,7\%. Mayoritas responden sebanyak 147 orang dengan persentase sebesar $64,75 \%$ yang mengikuti penelitian ini adalah mendapatkan uang saku sebanyak 500-750 ribu rupiah tiap bulannya dan kebanyakan dari mereka 130 orang $(57,3 \%)$ menghabiskan uang sakunya untuk berbelanja tanpa sisa.

\section{Deskripsi Data Penelitian}

Hasil deskripsi statistik pada tabel 1 (terlampir) menunjukkan bahwa perilaku konsumtif memiliki nilai rata-rata teoretis sebesar 85 dan nilai rata-rata empiris sebesar 71,37 dan menghasilkan perbedaan sebesar 13,63 dengan nilai t sebesar 27,473 dan signifikansi sebesar 0,000. Nilai rata-rata empiris yang diperolah lebih kecil dari rata-rata teoretis (mean empiris $<$ mean teoritis) yang menunjukkan bahwa kebanyakan responden dalam penelitian ini memiliki taraf perilaku konsumtif yang rendah dibanding dengan populasi.

Hasil deskripsi statistik pada tabel 1 menunjukkan bahwa konformitas memiliki nilai rata-rata teoretis sebesar 62,5 dan nilai rata-rata empiris sebesar 58,75 dan menghasilkan perbedaan sebesar 3,75 dengan nilai t sebesar -8,502 dan signifikansi sebesar 0,000 . Nilai rata-rata empiris yang diperolah lebih kecil dari rata-rata teoretis (mean empiris $<$ mean teoritis) yang menunjukkan bahwa kebanyakan responden dalam penelitian ini memiliki tingkat konformitas yang rendah dibandingkan dengan populasi. 
Hasil deskripsi statistik pada tabel 1 menunjukkan bahwa citra tubuh memiliki nilai rata-rata teoretis sebesar 57,5 dan nilai rata-rata empiris sebesar 57,46 dan menghasilkan perbedaan sebesar 0,4 dengan nilai t sebesar -7,007 dan signifikansi sebesar 0,000. Nilai rata-rata empiris yang diperolah lebih kecil dari rata-rata teoretis (mean empiris < mean teoritis) yang menunjukkan bahwa kebanyakan responden dalam penelitian ini memiliki citra tubuh yang rendah atau dapat dikatakan memiliki citra tubuh yang negatif dibanding dengan populasi.

\section{Uji Asumsi}

Uji normalitas dilakukan dengan menggunakan teknik Kolmogorov-Smirnov. Apabila taraf signifikansi lebih besar dari 0,05 ( $>0,05)$, maka data dapat dikatakan normal (Riadi, 2016). Hasil uji normalitas pada tabel 2 (terlampir) menunjukkan variabel perilaku konsumtif memiliki taraf signifikansi sebesar 0,279 $(\mathrm{p}>0,05)$, variabel konformitas memiliki taraf signifikansi $0,115(\mathrm{p}>0,05)$, dan variabel citra tubuh menunjukkan taraf signifikansi sebesar 0,240 ( $p>0,05)$. Berdasarkan hasil tersebut, maka dapat disimpulkan bahwa pada ketiga variabel tersebut sebaran datanya berdistribusi normal.

Teknik yang digunakan untuk menguji linearitas adalah Ramsey Test. Untuk melakukan uji ini, terlebih dahulu harus diasumsikan bahwa fungsi yang benar adalah fungsi yang linear. Rumus yang digunakan untuk mendapatkan hasil Fhitung adalah sebagai berikut:

Fhitung $=\left(R^{2}\right.$ new $-R^{2}$ old $) / m /\left(1-R^{2}\right.$ new $) /(n-k)$

Keterangan:

$\mathrm{m}=$ jumlah variabel independen yang baru masuk

$\mathrm{n}=$ jumlah data observasi

$\mathrm{k}=$ banyaknya parameter dalam persamaan yang baru

$\mathrm{R}^{2}$ new $=$ nilai $\mathrm{R}^{2}$ dari persamaan regresi baru

$\mathrm{R}^{2}$ old $=$ nilai $\mathrm{R}^{2}$ dari persamaan awal

Berdasarkan pada perhitungan yang telah dilakukan, diketahui bahwa nilai F-hitung yang didapatkan sebesar 0,49. Untuk mengetahui model regresi dalam bentuk linear, F-hitung selanjutnya dibandingkan dengan F-tabel, nilai F-tabel yang didapatkan adalah sebesar 2,56 dengan bantuan perhitungan melalui program SPSS. Jika dibandingkan, maka diketahui bahwa F-hitung lebih kecil dari F-tabel sehingga model regresi dalam bentuk linear.

Uji multikolinearitas dilakukan dengan melihat nilai Tolerance dan VIF. Apabila nilai Tolerance lebih besar sama dengan 0,1 (Tolerance $\geq 0,1$ ) dan nilai VIF lebih kecil sama dengan $10 \quad(\mathrm{VIF} \leq 10)$, maka dikatakan tidak terjadi multikolinieritas. Hasil uji mulitikolinieritas pada tabel 3 (terlampir) menunjukkan nilai Tolerance pada variabel konformitas sebesar 0,993 dan nilai VF sebesar 1,007. Begitu pula pada variabel citra tubuh dengan nilai Tolerance menunjukkan angka 0,993 dan nilai VIF sebesar 1,007.
Berdasarkan hasil tersebut, maka disimpulkan bahwa tidak terjadi multikolinieritas antara variabel bebas.

Uji heteroskedastisitas dilakukan menggunakan uji Glejser. Nilai signifikansi harus lebih besar dari 0.05 ( $\mathrm{p}>0,05)$ untuk membuktikan tidak terjadi masalah heteroskedastisitas. Hasil uji heteroskedastisitas pada tabel 4 (terlampir) menujukkan bahwa taraf signifikansi pada variabel konformitas sebesar $0,151(\mathrm{p}>0,05)$ dan taraf signifikansi pada variabel citra tubuh sebesar 0,307 $(\mathrm{p}>0,05)$. Berdasarkan hasil tersebut, maka dapat disimpulkan bahwa tidak terjadi heteroskedastisitas pada penelitian ini.

\section{Uji Hipotesis}

Uji hipotesis yang dilakukan dalam penelitian ini menggunakan teknik analisis regresi berganda. Uji regresi berganda dilakukan untuk mengetahui apakah variabel bebas konformitas dan citra tubuh dapat memprediksi munculnya variabel perilaku konsumtif pada remaja putri. Variabel bebas dikatakan berpengaruh secara signifikan terhadap variabel tergantung jika pada uji regresi, taraf signifikansinya lebih kecil dari 0,05 $(\mathrm{p}<0,05)$ (Santoso, 2014).

Dari hasil uji regresi berganda pada tabel 5, dapat dilihat taraf signifikansi yang diperoleh adalah sebesar $0,000(\mathrm{p}<0,05)$, dimana disebutkan apabila taraf signifikansi lebih kecil dari $0,05(\mathrm{p}<0,05)$ menunjukkan bahwa $\mathrm{H}_{0}$ ditolak dan $\mathrm{H}_{\mathrm{a}}$ diterima. Hipotesis mayor diterima menunjukkan bahwa model regresi dalam penelitian ini dapat digunakan untuk memprediksi perilaku konsumtif pada remaja putri, dengan kata lain konformitas dan citra tubuh secara bersama-sama berperan terhadap perilaku konsumtif pada remaja putri.

Pada tabel 6 (terlampir), dapat dilihat koefisien regresi (R) sebesar 0,335 dan koefisien determinasi ( $R$ Square) sebesar 0,113 . Perolehan koefisien regresi (R) sebesar 0,335 menunjukkan bahwa terdapat hubungan positif antara variabel bebas yaitu konformitas dan citra tubuh terhadap perilaku konsumtif pada remaja putri. Perolehan koefisien determinasi ( $R$ square) sebesar 0,113 menunjukkan bahwa konformitas dan citra tubuh secara bersama-sama memberikan peran sebesar $11,3 \%$ terhadap perilaku konsumtif, sedangkan sisanya $88,7 \%$ ditentukan oleh faktor-faktor lain yang tidak diteliti.

Hasil uji hipotesis minor dengan analisis regresi berganda pada tabel 7 (terlampir) menunjukkan variabel konformitas memiliki koefisien beta tidak terstandarisasi sebesar 0,378 dan nilai t sebesar 5,318 dengan taraf signifikansi sebesar 0,000 $(\mathrm{p}<0,05)$ yang berarti konformitas secara mandiri berperan secara signifikan terhadap perilaku konsumtif pada remaja putri. Variabel citra tubuh memiliki koefisien beta tidak terstandarisasi sebesar 0,052 dengan nilai t sebesar 0,810 dan taraf signifikansi sebesar $0,419(\mathrm{p}>0,05)$ yang berarti citra tubuh secara mandiri tidak berperan secara signifikan terhadap perilaku konsumtif pada remaja putri. 
Penelitian ini menggunakan dua variabel bebas, sehingga didapatkan persamaan garis regresi sebagai berikut:

$\mathrm{Y}=46,185+0,378 \mathrm{X} 1+0,052 \mathrm{X} 2$.

Keterangan:

$\mathrm{Y}=$ Perilaku konsumtif

$\mathrm{X} 1=$ Konformitas

$\mathrm{X} 2=$ Citra tubuh

Persamaan garis regresi tersebut memiliki arti sebagai berikut: a. Konstanta sebesar 46,185 memiliki arti bahwa jika tidak penambahan atau peningkatan skor pada variabel konformitas dan citra tubuh, maka taraf perilaku konsumtif pada remaja putri adalah sebesar 46,185

b. Koefisien regresi X1 sebesar 0,378 memiliki arti bahwa setiap penambahan atau peningkatan satuan nilai responden pada variabel konformitas, maka akan terjadi kenaikan sebesar 0,378 pada taraf perilaku konsumtif.

c. Koefisien regresi X2 sebesar 0,052 memiliki arti bahwa setiap penambahan atau peningkatan satuan nilai responden pada variabel citra tubuh, maka akan terjadi kenaikan pada taraf perilaku konsumtif sebesar 0,052 .

Ringkasan hasil uji hipotesis mayor dan uji hipotesis minor dalam penelitian ini, dapat dilihat pada tabel 8 (terlampir).

\section{PEMBAHASAN DAN KESIMPULAN}

\section{Pembahasan Hipotesis Mayor}

Berdasarkan hasil analisis uji regresi berganda yang telah dilakukan, diperoleh hasil bahwa citra tubuh dan konformitas bersama-sama berperan secara signifikan terhadap perilaku konsumtif pada remaja putri di Denpasar. Citra tubuh dan konformitas secara bersama-sama memberikan peran sebanyak $11,3 \%$ terhadap perilaku konsumtif sedangkan $88,7 \%$ dipengaruhi oleh faktor-faktor lain.

Adanya peran citra tubuh dan konformitas terhadap perilaku konsumtif pada remaja putri didukung oleh penelitian yang dilakukan oleh Sebayang (2011) yang menemukan terdapat hubungan antara citra tubuh dan konformitas terhadap perilaku konsumtif. Perilaku konsumtif adalah suatu tindakan yang tidak rasional dan bersifat kompulsif sehingga dapat menyebabkan pemborosan dan infisiensi biaya. Individu dengan tindakan tidak rasional dan kompulsif merasa belum lengkap dan mencari kepuasan dengan membeli barangbarang yang baru walaupun mereka masih memiliki barangbarang yang belum habis atau bahkan belum pernah dipakai sama sekali (Zebua dan Nurdjayati, 2001).

Remaja yang berada pada masa peralihan dari masa kanakkanak dengan suasana hidup penuh ketergantungan pada orangtua menuju masa dewasa yang bebas dan mandiri serta matang (Santrock, 2003). Remaja akan berusaha untuk menampilkan jati diri yang terbaik termasuk penampilan fisik, dimana pada masa ini penampilan menjadi perhatian yang besar (Hurlock, 2006). Cash dan Pruzinsky (2002) mengatakan adanya perasaan tidak puas terhadap tubuh dan pandangan mereka terhadap penampilan mereka berhubungan dengan citra tubuh seseorang. Perhatian terhadap penampilan fisik ditunjukkan melalui kekhawatiran dan perilaku membeli mereka terhadap barang yang dirasa dapat meningkatkan penampilan.

Perilaku konsumtif pada remaja juga terkait dengan tingkat konformitas terhadap kelompok acuan. Menurut Baron dan Byrne (2003), konformitas adalah penyesuaian remaja untuk mengikuti norma dalam kelompok, menerima ide dan aturanaturan bagaimana remaja berperilaku. Berdasarkan penelitian yang dilakukan oleh Sihotang (2009), adanya keinginan untuk diterima oleh kelompok membuat remaja cenderung lebih memperhatikan penampilan mereka. Banyak usaha yang dilakukan yang membuat remaja harus bertingkah laku maupun berpenampilan sama dengan pola-pola dan harapanharapan sesama anggota kelompoknya. Remaja akan mulai memfokuskan diri pada penampilan baik penampilan fisik, pakaian, rambut maupun wajah. Remaja akan terus menerus membeli barang-barang yang dapat menunjang penampilan mereka walaupun barang-barang yang mereka miliki masih bermanfaat. Ketaatan untuk selalu tampil sama dengan kelompok dapat mendorong remaja untuk melakukan pembelian secara tidak wajar.

\section{Pembahasan Hipotesis Minor Satu}

Hipotesis minor pertama berbunyi terdapat hubungan yang negatif antara citra tubuh dengan perilaku konsumtif pada remaja putri di Universitas Udayana. Berdasarkan hasil analisis koefisien beta terstandarisasi dari citra tubuh menunjukkan nilai sebesar 0,051 dengan nilai t sebesar 0,810 dengan taraf signfikansi sebesar $0,419(p>0,05)$ yang berarti citra tubuh secara mandiri tidak berperan secara signifikan terhadap perilaku konsumtif pada remaja putri.

Masa remaja merupakan suatu periode transisi antara anakanak dan dewasa (Santrock, 2004). Perubahan yang paling terlihat jelas pada masa remaja adalah perubahan dari sisi biologis, sehingga keadaan tubuh merupakan salah satu hal yang sangat diperhatikan oleh remaja, terutama remaja putri. Mereka juga akan mencari dan mencoba berbagai cara untuk membuat fisik mereka terlihat menarik. Namun, menurut Kartono (dalam Haryanto, 2010) remaja akhir yang berada dalam rentang 18 hingga 21 tahun sudah pada keadaan yang mantap dan stabil. Perkembangan aspek-aspek psikis yang telah dimulai pada tahapan sebelumnya, telah mengarah pada kematangan yang sempurna, sehingga perhatian remaja tidak lagi selalu kepada penampilan namun lebih kepada tugas-tugas perkembangan lainnya dan mempersiapkan diri untuk menghadapi masa dewasa (Steinberg, 2002).

Pendapat lain menurut Zimbardo (1992) dimana individu pada masa remaja akan memiliki beberapa tugas perkembangan mengenai kematangan fisik dan psikisnya. Salah satu tugas perkembangan yang harus dipenuhi adalah menerima kondisi fisiknya dan memanfaatkan tubuhnya secara efektif. Dapat menerima diri sendiri berarti mengembang-kan physical self (bagian yang berkaitan dengan keadaan tubuh) dan dapat menerima gambaran penampilan fisiknya (Zimbardo, 1992). 
Saat remaja dapat menerima keadaan fisiknya dan telah menilai dirinya lebih positif, hal ini akan menyebabkan kecenderungan untuk melakukan pembelian barang akan lebih didasari oleh perencanaan dan pertimbangan yang lebih matang. Hal ini terjadi karena individu sudah lebih bisa menerima dirinya pada usia remaja akhir sehingga mereka cenderung tidak akan mudah terpengaruh oleh berbagai bentuk promosi yang kreatif dan inovatif dari suatu barang (Astasari dan Sahrah, 2009). Saat individu dapat menerima keadaan dirinya, mereka akan menunjukkan pula rasa percaya diri dan yakin akan kemampuan yang dimiliki diri sendiri. Seseorang yang memiliki kepercayaan diri tidak akan merasa cemas dan melakukan tindakan yang tidak rasional, sehingga keputusan yang diambil sudah dipikirkan secara matang dan rasional (Ridha, 2012).

Menjelaskan lebih lanjut mengenai hasil penelitian mengenai penilaian citra tubuh, Stuart dan Laraia (2005) mengemukakan bahwa citra tubuh merupakan sesuatu yang dinamis. Hal ini dikarenakan citra tubuh dapat berubah secara kontinu seiring dengan adanya pengalaman dan persepsi baru. Pernyataan yang sama juga dinyatakan oleh Waller dan Barner (2002) dimana citra tubuh dapat menjadi sebuah konstruk yang dinamis yang bergantung pada faktor sosial dan psikologis individu.

\section{Pembahasan Hipotesis Minor Dua}

Hipotesis minor kedua berbunyi terdapat hubungan yang positif antara konformitas dengan perilaku konsumtif pada remaja putri di Universitas Udayana. Berdasarkan hasil analisis koefisien beta terstandarisasi dari konformitas menunjukkan nilai sebesar 0,336 dengan nilai t sebesar 5,318 dan taraf signifikasi sebesar $0,000(p<0,05)$ yang berarti konformitas secara mandiri berperan secara signifikan terhadap perilaku konsumtif pada remaja putri.

Menurut penelitian yang dilakukan Fitriyani, Widodo dan Fauziah (2013), munculnya hubungan antara konformitas dengan perilaku konsumtif pada hakikatnya disebabkan karena adanya faktor eksternal yang berperan. Interaksi yang intensif antara teman-teman satu kelompok membuat satu sama lain saling mempengaruhi. Sumartono (2002) menyatakan bahwa dalam menentukan produk yang akan dikonsumsinya, seseorang akan melihat kelompok acuannya dimana pada umumnya individu akan cenderung untuk konformis atau menunjukkan sikap yang searah dengan kelompok.

Keinginan untuk diterima dalam kelompok, mendorong remaja untuk melakukan berbagai cara untuk dapat sesuai dengan kelompoknya, terutama dalam hal mengkonsumsi barang dan dapat memunculkan perilaku konsumtif. Perilaku konsumtif diawali dengan munculnya keinginan berlebihan untuk memiliki suatu barang. Keinginan tidak didasarkan pada kebutuhan namun untuk simbol status (Lubis, dalam Sumartono, 2002). Perilaku konsumtif adalah suatu perilaku yang tidak lagi didasarkan pada pertimbangan yang rasional namun karena adanya keinginan yang sudah mencapai taraf tidak rasional lagi.
Salah satu faktor yang mempengaruhi perilaku konsumtif adalah karena pengaruh kelompok acuan. Kelompok acuan memiliki pengaruh yang cukup kuat dalam membentuk kepribadian dan perilaku seseorang. Schiffman dan Kanuk (2004) menjelaskan bahwa kelompok acuan memiliki pengaruh kuat karena kelompok dapat menjadi tempat bagi individu untuk melakukan perbandingan, menyediakan informasi dan petunjuk dalam memilih apa yang akan dikonsumsi.

Berdasarkan penelitian Glock (dalam Sumartono, 2002) mengungkapkan bahwa konsumsi yang berlebihan sangat ditentukan oleh sikap mudah terpengaruh oleh kelompok acuan, dimana hal ini sesuai dengan karakter remaja yang mudah dipengaruhi oleh kelompok sebaya dan kelompok refrensinya, serta memiliki kontrol eksternal yang lebih tinggi dari kontrol internal. Dalam menggunakan uangnya untuk berbelanja, remaja dinilai kurang efisien karena pembelian barang bukan berdasarkan kebutuhan namun karena adanya keinginan untuk meniru orang lain, mencoba produk baru dan memperoleh pengakuan sosial.

Pride dan Ferrell (dalam Sihotang, 2009) menyatakan bahwa kelompok acuan dapat mempengaruhi keputusan pembelian bergantung pada sejauh mana individu tersebut konform dan terpengaruh oleh kelompok serta seberapa besar keterlibatannya didalam kelompok. Bagi remaja, hubungan dengan teman sebaya menjadi sarana untuk mengamati dan meneliti minat serta pandangan teman sebaya dengan tujuan untuk memudahkan proses penyatuan dirinya kedalam aktivitas teman sebaya. Penyesuaian dilakukan agar tercapai tujuan dan keselarasan dengan anggota kelompok (Willis, dalam Sarwono, 2012).

Berdasarkan hasil penelitian yang telah dipapakan, maka dapat disimpulkan bahwa citra tubuh dan konformitas secara bersama-sama dapat mempengaruhi munculnya perilaku konsumtif dan memberikan peran sebesar $11,3 \%$ dalam memprediksi variabel perilaku konsumtif pada remaja putri di Universitas Udayana. Konformitas secara mandiri dapat mempengaruhi munculnya perilaku konsumtif pada remaja putri di Universitas Udayana. Citra tubuh secara mandiri tidak mempengaruhi munculnya perilaku konsumtif dan hanya akan berpengaruh apabila bersama-sama dengan variabel konformitas. Hal ini dikarenakan skala citra tubuh yang digunakan lebih mengukur citra tubuh secara umum dan kurang mengukur dalam hubungannya dengan perilaku berbelanja dalam menunjang penampilan diri.

Taraf perilaku konsumtif pada remaja putri di Universitas Udayana tergolong rendah karena pada fase remaja akhir, individu akan melakukan pembelian berdasarkan pertimbangan yang lebih rasional serta dengan perencanaan yang lebih matang.. Tingkat konformitas pada remaja remaja putri di Universitas Udayana tergolong rendah karena seiring bertambahnya usia, individu akan mengurangi tingkat konformitas dengan kelompok acuannya. Citra tubuh yang dimiliki oleh mahasiswi Universitas Udayana tergolong rendah atau memiliki citra tubuh yang negatif karena adanya pengaruh dari lingkungan dan media massa yang membuat 
remaja membandingkan diri dengan orang lain serta tuntutan sosial yang menekankan bahwa perempuan harus tampil menarik, sehingga remaja seringkali merasa tidak puas dengan penampilan mereka sendiri.

Saran yang dapat diberikan pada remaja putri adalah dengan mempertahankan dan mengontrol perilaku membeli agar nantinya tidak terjebak dalam perilaku konsumtif. Salah satu cara yang dapat dilakukan adalah menjadi pribadi yang mandiri dan tidak terpengaruh oleh pengaruh kelompok yang dapat menjerumuskan ke hal-hal yang negatif. Remaja juga dapat memilah-milah kegiatan dalam kelompok yang dapat memfasilitasi diri untuk mengembangkan potensi serta prestasi. Remaja juga diharapkan dapat memanfaatkan uang dengan bijaksana dan lebih seletif dalam melakukan pembelian, dimana pembelian diprioritaskan pada hal-hal yang memang sesuai dengan kebutuhan.

Saran yang dapat disarankan bagi orangtua untuk terus memberikan pemahaman, mengawasi dan mengontrol anak terutama dalam hal berbelanja agar tidak mengikuti arus belanja untuk menghindari pola perilaku berbelanja yang berlebihan. Selain itu, orangtua juga diharapkan untuk lebih mengarahkan anak untuk membentuk pemikiran dan tindakan yang lebih rasional untuk kegiatan yang sekiranya dapat menimbulkan perilaku konsumtif atau memberikan pengertian bahwa segala yang dilakukan oleh orang lain tidak harus diikuti dan tidak harus sama dengan orang lain.

Bagi peneliti selanjutnya yang akan melakukan penelitian mengenai perilaku konsumtif, diharapkan untuk memperhatikan faktor-faktor lain yang turut berperan dalam mendorong munculnya perilaku konsumtif seperti faktor budaya dan sosial karena perilaku konsumtif merupakan suatu fenomena yang akan terus berkembang dan menjadi hal yang tidak bisa dipisahkan dalam kehidupan sehari-hari. Hendaknya juga untuk menambahkan teori-teori terbaru sebagai teori pendukung serta untuk menggunakan sampel penelitian yang berbeda, sehinggal hal ini akan memperluas wawasan dan pengetahuan serta dapat menjadi pembanding hasil penelitian sebelumnya. Disarankan untuk memperluas subjek penelitian atau mengambil kelompok subjek dengan latar belakang yang berbeda, seperti perempuan pada dewasa awal. Disarankan pula untuk memperhatikan ketepatan pemilihan subjek dengan karakteritistik subjek yang lebih spesifik.

\section{DAFTAR PUSTAKA}

Adi, P.S (2008). Membentuk body image positif. Majalah Psikologi Plus, 2(12). 61-66. Diakses dari https:/jurnalwacana.psikologi.fk.uns.ac.id.

Andriany, D., Prastuti, E., \& Setiyowati, N. (2011). Hubungan antara body image dengan perilaku konsumtif dalam pembelian produk kosmetik pada siswi kelas X SMK Negeri 2 Malang (Skripsi, Universitas Negeri Malang). Diambil dari http://karya-ilmiah.um.ac.id/index.php/BKPsikologi/article/view/12496.

Anin, A., Rasimin \& Atamimi, N. (2007). Hubungan self monitoring dengan impulsive buying terhadap produk fashion pada remaja. Jurnal Psikologi, 35(2). 181-193. Diakses dari https://journal.ugm.ac.id/jpsi/article/view/7951.
Aryani, G. (2006). Hubungan antara konformitas dan perilaku konsumtif pada remaja di SMA Negeri 1 Semarang (Skripsi, Universitas Negeri Semarang). Diambil dari https://lib.unnes.ac.id/1497.

Astasari \& Sarah, (2009). Hubungan antara konformitas dengan perilaku membeli impulsif pada remaja putri (Skripsi, Universitas Wangsa Manggala). Diambil dari https://fpsi.mercubuana-yogya.ac.id.

Azwar, S. (2010a). Penyusunan skala psikologi. Jogjakarta: Pustaka Pelajar.

Azwar, S. (2010b). Reliabilitas dan validitas. Jogjakarta: Pustaka Pelajar.

Bani, A. (2002). Studi tentang persepsi mahasiswa terhadap tubuh ideal dan hubungannya dengan pencapaiannya (Skripsi, Institut Pertanian Bogor). Diambil dari https://repository.ipb.ac.id/bitstream/123456789/12727/2/A 02aba.pdf.

Baron, A. R., \& Byrne, D. (2003). Psikologi sosial (Jilid 1). Jakarta: Erlangga.

Cash, T. F., \& Pruzinsky, T. (2002). Body image: A handbook of theory, research, and clinical practice. New York: The Guilford Press.

Djudiyah \& Hadipranata, A. F. (2002). Hubungan pemantauan diri, harga diri, materialisme, dan uang saku dengan pembelian impulsif pada remaja. Jurnal Psikodinamik, 3(2). 57-72. Diakses dari eprints.umm.ac.id/30013/jiptummb-dianrachma-27766-2.pdf

Engel, J. F., Blackwell, R. D., \& Miniard, P. W. (2008). Perilaku Konsumen (Jilid 1). Tangerang: Binarupa Aksara

Field, A. (2009). Discovering statistics using IBM SPSS statistics (4th ed). London: SAGE Publications Ltd. 
Fitriyani, N., Widodo, P.B, \& Fauziah, N. (2013). Hubungan antara konformitas dengan perilaku konsumtif pada mahasiswa di Genuk Indah Semarang. Jurnal Psikologi, 12. 55-68. doi: 10.14710/jpu.12.1.1-14.

Fransisca \& Suyasa, P. T. (2005). Perbandingan perilaku konsumtif berdasarkan metode pembayaran. Jurnal Phronesis, 7(2). 172-199. Diakses dari https://www.researchgate.net/publication/319751850_Perba ndingan_Perilaku_Konsumtif_berdasarkan_Metode_Pemba yaran

Gozhali, I. (2005). Aplikasi analisis multivariate dengan program SPSS. Semarang: Badan Penerbit Undip.

Grogan, S. (2008). Body image: Understanding body dissatisfaction in men, women and children (2nd ed). New York: Routledge.

Green, M., \& Palfrey, J. S. (2008). Bright futures: Guidelines for health supervision of infants, children, and adolescents (3rd ed). Arlington, VA: National Center for Education in Maternal and Child Health.

Hadi, S. (2004). Statistika (Jilid 2). Jogjakarta: Andi.

Hurlock, E. B. (2006). Psikologi perkembangan: Suatu pendekatan sepanjang rentang kehidupan (Edisi ke-5). Jakarta: Erlangga.

Indria, K., \& Nindyati, A. D. (2007). Kajian konformitas dan kreativitas affective remaja. Jurnal Provitae, 3(1). 85-110. Diakses

dari

https://knowledge.paramadina.ac.id/index.php/filedownload/viewdownload/41-publication/486-kajiankonformitas-dan-kreativitas-affective-remaja.

Januar, V., \& Putri, D. E., (2007). Citra tubuh pada remaja putri menikah dan memiliki anak. Jurnal Psikologi, 1(1). 52-62. Diakses

dari https://media.neliti.com/media/publications/97697- IDnone.pdf.

Keliat, B. A. (1998). Proses Keperawatan Kesehatan. Jakarta: EGC.

Kotler, P., \& Keller, K. L. (2008). Manajemen Pemasaran (Jilid 1). Jakarta: P.T. Indeks.

Kotler, P., \& Susanto. (2000). Manajemen Pemasaran di Indonesia (Jilid 1). Jakarta: Salemba Empat.

Longe, J. L. (2008). Gale encyclopedia of diets: A guide to health and nutrition. Farmington Hills: The Gale Group.

Mangkunegara, A. P. (2005). Perilaku Konsumen. Bandung: PT. Refika Aditama.

Mighwar, M. (2006). Psikologi Remaja. Bandung: Pustaka Setia.

Monks, F., Knoers, A., \& Hadinoto, S. (2014). Psikologi perkembangan: Pengantar dan berbagai bagiannya. Yogyakarta: Gadjah Mada University Press.

Myers, D. G. (2002). Social Psychology (7th ed). New York: McGraw Hill.

Ningsih, R. A. A. S., \& Bawono, Y. (2016). Hubungan antara perilaku konsumtif pada produk X dengan citra diri remaja putri. Jurnal Mediapsi, 2(1). 45-50. Diakses dari http://mediapsi.ub.ac.id/index.php/mediapsi/article/downlo $\mathrm{ad} / 14 / 12$.

Papalia, D. E., Olds, S. W., \& Feldman, R. D. (2013). Human Development (10th ed). Jakarta: Penerbit Salemba Humanika.

Prasetijo, R., \& Ihalauw, J. (2005). Perilaku Konsumen. Yogyakarta: Andi.

Purwanto. (2008). Metodelogi penelitian kuantitatif: untuk psikologi dan pendidikan. Yogyakarta: Pustaka Pelajar.

Rakhmat, J. (2009). Psikologi Komunikasi. Bandung: P.T. Remaja Rosdakarya.

Riadi, E. (2016). Statistika penelitian (analaisis manual dan IBM SPSS). Yogyakarta: ANDI Yogyakarta.
Ridha, M. (2012). Hubungan antara body image dengan penerimaan diri pada mahasiswa Aceh di Yogyakarta. Jurnal EMPATHY, 1(1). 111-121. Diakses dari http://id.portalgaruda.org/?ref=browse \& $\bmod =$ viewarticle \& article $=123297$.

Riduwan. (2012). Pengantar Statistika Sosial. Bandung: Alfabeta.

Rohman, J., \& Baidun, A. (2013). Pengaruh citra diri (self image) dan konformitas terhadap perilaku compulsive buying pada remaja. Jurnal Psikologi, 18(2). 281-297. Diakses dari http://download.portalgaruda.org/article.php?article $=40208$ $3 \& v a l=6847$

Rosandi, A. F. (2004). Perbedaan perilaku konsumtif antara mahasiswa pria dan wanita di Universitas Katolik Atma Jaya (Skripsi, Universitas Atma Jaya). Retrieved from http://core.ac.uk/download/pdf/78392472.pdf.

Rosha, B., Utami, N. H., \& Rachmalina, R. (2013). Peer group dan uang saku bulanan meningkatkan resiko persepsi body image negatif pada remaja putri di Bekasi. Jurnal Ekologi Kesehatan, 12 (4). 295-303. Diakses dari http://ejournal.litbang.depkes.go.id/index.php/jek/article/vi $\mathrm{ew} / 5351$

Santoso, B. (2006). Bebas dari konsumerisme. Yogyakarta: Andi.

Santoso, S. (2014). Panduan lengkap SPSS versi 20. Jakarta: Elex Media Komputindo.

Santrock, J. W. (2003). Adoloscence: Perkembangan remaja. Jakarta: Erlangga.

Sarwono, S. (2012). Psikologi sosial. Jakarta: Salemba Humanika.

Schiffman, L. G., \& Kanuk, L. (2004). Perilaku konsumen (edisi ke7). Jakarta: PT. Indeks Gramedia.

Sears, D. O., Freedman, J. L., Peplau, \& Letitia, A. (2009). Psikologi sosial (Jilid 2, Edisi ke-5). Jakarta: Erlangga.

Sebayang, J., Yusuf, M., \& Priyatama, A. N. (2011). Hubungan antara body image dan konformitas dengan perilaku konsumtif pada siswi kelas XI SMA Negeri 7 Surakarta (Skripsi, Universitas Sebelas Maret). Diambil dari https://eprints.uns.ac.id/8120/.

Sihotang, A. (2009). Hubungan antara konformitas terhadap kelompok teman sebaya dengan pembelian impulsif remaja (Skripsi, Universitas Diponegoro). Diambil dari https://eprints.uns.ac.id/8120/pdf.

Sobur, A. (2003). Psikologi Umum. Bandung: C.V. Pustaka Setia.

Solomon, M. R. (2007). Consumer behavior: Buying, having and being (7th ed). New Jersey: Pearson Education, Inc.

Sugiyono. (2012). Metode penelitian kuantitatif, kualitatif dan kombinasi (mixed methods). Bandung: Alfabeta.

Sukamto, M. E. (2006). Citra tubuh perempuan di media massa. Jurnal Psikologi, 21(3). 299-305. Diakses dari www.anima.ubaya.ac.id/class/openpdf.php?file $=13505283$ 17.pdf.

Sumartono. (2002). Terperangkap dalam iklan: Meneropong imbas pesan iklan televisi. Bandung: Alfabeta.

Sunarto. (2003). Prinsip-prinsip pemasaran. Yogyakarta: Kampus Kebangsaan Universitas Sarjanawiyata Tamansiswa.

Suryabrata, S. (2006). Metodelogi penelitian. Jakarta: PT. Raja Grafindo Persada.

Stuart, G. W., \& Laraia, M. T. (2005). Principle and practice of psychiatric nursing (8th ed). St. Louis: Mosby.

Steinberg, L. (2002). Adolescence (6th ed). USA : McGraw Hill.

Tambuan, R. (2001, 10 Maret). Remaja dan Perilaku Konsumtif. Media dan Konsultasi Psikologi. Diakses 26 November, 2016, dari http://e-psikologi.com.

Taylor, P., \& Sears. (2009). Psikologi sosial (edisi ke-12). Jakarta: Kencana Prenada Media Group.

Thompson, J. K. (2000). Body image, eating disorders, and obesity: An intergrative guide for assesment and treatment. Washington DC: American Psychological Association. 
Usman, H., \& Akbar, P. S. (2000). Metodelogi penelitian sosial. Jakarta: PT. Bumi Aksara.

Waller, G., \& Barnes, J. (2002). Preconscious processing of body image cues: Impact on body percept and concept. Journal of Psychosomatic Research, 53(10). 1037-1041. Diakses dari

https://www.sciencedirect.com/science/article/pii/S002239 9902004920

Zebua, A. S., \& Nurdjayati, R. D. (2001). Hubungan antara konformitas dan konsep diri dengan perilaku konsumtif pada remaja putri. Jurnal Phronesis, 3(6). 72-82. Diakses dari https://philarchive.org/rec/ZEBHAK.

Zimbardo, P. G. (2007). Psychology and life (18th ed). Boston: Pearson. 


\section{LAMPIRAN}

Tabel 1

Deskripsi Statistik Data Penelitian

\begin{tabular}{cccc}
\hline Deskripsi Data & $\begin{array}{c}\text { Perilaku } \\
\text { Konsumtif }\end{array}$ & Konformitas & Citra tubuh \\
\hline N & 227 & 227 & 227 \\
Mean Teoretis & 85 & 62,5 & 57,5 \\
Mean Empiris & 71,37 & 58,75 & 57,46 \\
Std. Deviasi Teoretis & 17 & 12,5 & 11,2 \\
Std. Deviasi Empiris & 7,472 & 6,647 & 7,312 \\
Skor Minimal & 46 & 27 & 32 \\
Skor Maksimal & 89 & 78 & 81 \\
Sebaran Teoretis & $34-136$ & $25-100$ & $23-92$ \\
Sebaran Empiris & $46-89$ & $27-87$ & $32-81$ \\
t & $-27,473$ & $-8,502$ & $-7,7007$ \\
& $\mathrm{p}=(0,000)$ & $\mathrm{p}=(0,000)$ & $\mathrm{p}=(0,000)$ \\
\hline
\end{tabular}

Tabel 2

Hasil Uji Normalitas Data Penelitian

\begin{tabular}{cccc}
\hline Variabel & Kolmogorov-Smirnov & $\begin{array}{c}\text { Asymp. Sig. (2-tailed) } \\
\text { (p) }\end{array}$ & Keterangan \\
\hline Perilaku Konsumtif & 0,911 & 0,279 & Data Normal \\
Konformitas & 1,195 & 0,115 & Data Normal \\
Citra tubuh & 1,029 & 0,240 & Data Normal \\
\hline
\end{tabular}

Tabel 3

Hasil Uji Multikolinearitas Data Penelitian

\begin{tabular}{cccc}
\hline Variabel & Tolerance & $\begin{array}{c}\text { Variance Inflation } \\
\text { Factor (VIF) }\end{array}$ & Keterangan \\
\hline Konformitas & 0,993 & 1,007 & $\begin{array}{c}\text { Tidak terjadi } \\
\text { multikolinieritas } \\
\text { Tidak terjadi }\end{array}$ \\
Citra tubuh & 0,993 & 1,007 & \begin{tabular}{c} 
multikolinieritas \\
\hline
\end{tabular} \\
\hline
\end{tabular}

Tabel 4

Hasil Uji Heteroskedastisitas Data Penelitian

\begin{tabular}{|c|c|c|c|c|c|c|}
\hline & \multirow[t]{2}{*}{ Model } & \multicolumn{2}{|c|}{ Unstandardized Coefficients } & $\begin{array}{c}\text { Standardized } \\
\text { Coefficients }\end{array}$ & \multirow[t]{2}{*}{$\mathrm{t}$} & \multirow[t]{2}{*}{ Sig. } \\
\hline & & B & Std. Error & Beta & & \\
\hline \multirow{3}{*}{1} & (Constant) & 11,466 & 3,479 & & 3,296 & 0,001 \\
\hline & Konformitas & $-0,061$ & 0,042 & $-0,096$ & $-1,440$ & 0,151 \\
\hline & Citra tubuh & $-0,039$ & 0,039 & $-0,068$ & $-1,024$ & 0,307 \\
\hline
\end{tabular}


Tabel 5

Hasil Signifikansi Uji Regresi Berganda

\begin{tabular}{ccccccc}
\hline Model & & Sum of Squares & $\mathrm{df}$ & Mean Square & F & Sig. \\
\hline \multirow{4}{*}{1} & Regression & 1420,237 & 2 & 710,118 & 14,204 & 0,000 \\
& Residual & 11198,935 & 224 & 49,995 & & \\
& Total & 12619,172 & 226 & & & \\
\hline
\end{tabular}

Tabel 6

Besaran Peran Variabel Bebas terhadap Variabel Tergantung

\begin{tabular}{ccccc}
\hline Model & $\mathrm{R}$ & $R$ Square & $\begin{array}{c}\text { Adjusted } R \\
\text { Square }\end{array}$ & $\begin{array}{c}\text { Std. Error of the } \\
\text { Estimate }\end{array}$ \\
\hline 1 & 0,335 & 0,113 & 0,105 & 7,071 \\
\hline
\end{tabular}

Tabel 7

Uji Hipotesis Minor dan Garis Regresi Berganda

\begin{tabular}{ccccccc}
\hline & Model & UnstardardizedCoefficients & $\begin{array}{c}\text { Standardized } \\
\text { Coefficients }\end{array}$ & $\mathrm{t}$ & \multirow{2}{*}{ Sig. } \\
\cline { 3 - 5 } & \multicolumn{3}{c}{$\mathrm{B}$} & Std. Error & Beta & \\
\hline \multirow{2}{*}{1} & (Constant) & 46,185 & 5,832 & & 7,919 & 0,000 \\
& Konformitas & 0,378 & 0,071 & 0,336 & 5,318 & 0,000 \\
& Citra tubuh & 0,052 & 0,065 & 0,051 & 0,810 & 0,419 \\
\hline
\end{tabular}

Tabel 8

Rangkuman Hasil Uji Hipotesis Penelitian

\begin{tabular}{llc}
\hline No & \multicolumn{1}{c}{ Hipotesis } & Hasil \\
\hline & $\begin{array}{l}\text { Hipotesis Mayor: } \\
\text { Terdapat hubungan antara citra tubuh dan konformitas dengan }\end{array}$ & Diterima \\
1. & $\begin{array}{l}\text { perilaku konsumtif pada remaja putri di Denpasar. } \\
\text { Hipotesis Minor: }\end{array}$ & Ditolak \\
& $\begin{array}{l}\text { Terdapat hubungan yang negatif antara citra tubuh dengan perilaku } \\
\text { konsumtif pada remaja putri di Denpasar. }\end{array}$ & \\
\hline & $\begin{array}{l}\text { Terdapat hubungan yang positif antara konformitas dengan perilaku } \\
\text { konsumtif pada remaja putri di Denpasar. }\end{array}$ & Diterima \\
\hline
\end{tabular}

